\title{
Catarata subcapsular posterior em pacientes com pênfigo e penfigóide tratados com corticoterapia oral ${ }^{*}$ Posterior subcapsular cataract in patients with pemphigus and pemphigoid using oral corticosteroid*
}

Viviane Reggiani ${ }^{1}$

Adriana Dias ${ }^{4}$

\author{
Adriana Maria Porro ${ }^{2}$ \\ Fernando Augusto de Almeida ${ }^{5}$
}

Cristiane Ramos Alonso ${ }^{3}$

\begin{abstract}
Resumo: FundAMENTO - 0 tratamento mais utilizado para pacientes com dermatoses bolhosas crônicas é a corticoterapia oral, muitas vezes em altas doses e por períodos prolongados. Como efeitos colaterais dessa terapêutica, freqüentemente ocorrem: hipertensão arterial, diabete, osteoporose, infecções e distúrbios hidroeletrolíticos. A catarata subcapsular posterior é raramente citada na literatura como efeito colateral da corticoterapia em pacientes com doenças bolhosas.

OBJETIVO - Avaliar a prevalência de catarata subcapsular posterior como efeito colateral da corticoterapia oral.

MÉTODOs - Trata-se de um estudo retrospectivo incluindo 49 pacientes com dermatoses bolhosas crônicas em uso de corticoterapia acompanhados entre janeiro de 1987 e dezembro de 1997 no ambulatório de Dermatoses Bolhosas do Departamento de Dermatologia da Unifesp/EPM e regularmente submetidos à avaliação oftalmológica em busca de catarata cortisônica.

RESULTADOS - No período de 1987 a 1997, 49 pacientes foram avaliados, tendo apresentado prevalência de catarata subcapsular posterior como efeito colateral da corticoterapia oral de $28,57 \%$.

CONCLUSÖES - 1) a prevalência de catarata foi de 28,57\%; 2) 0 tempo médio de tratamento até 0 surgimento de catarata foi de 45,71 meses; 3) a média da dose máxima de corticosteróide utilizada pelos pacientes foi de 78,57mg/dia. Palavras-chave: catarata; corticosteróides/uso terapêutico; pênfigo; penfigóide bolhoso.
\end{abstract}

\begin{abstract}
BACKGROUND - Oral corticosteroid is the treatment most used for patients with chronic bullous dermatosis, often at high dosages and over long periods of time. Arterial hypertension, diabetes, osteoporosis, infections and hydro-electrolytic disturbances frequently occur as side effects of this therapy. Posterior subcapsular cataract is rarely mentioned in the literature as a side effect of corticosteroid in patients with bullous diseases.

OBJECTIVES - To evaluate the incidence of posterior subcapsular cataract as a side effect of oral corticosteroid.

METHODS - A retrospective study: 49 patients with chronic bullous diseases using a corticosteroid were followed-up from 1987 to 1997 at the Bullous Dermatosis Outpatient Care Unit of the Department of Dermatology, UNIFESP . EPM. The patients were regularly submitted to ophthalmologic evaluation in search for cortisone cataract. This eval uation was carried out at the beginning of the treatment and regularly during the use of the corticosteroid.

RESULTS- From 1987 to 1997, the incidence of posterior subcapsular cataract as a side effect of oral corticosteroid was $28.57 \%$ in these patients.

Conclusions - 1) among 49 patients, 14 (28.57\%) presented with cortisone cataract. 2) the period of time of prednisone use up to the appearance of cataract varied from eight months to nine years and three months (average 45.71 months). 3) the maximum dose of oral corticosteroid required for the management of the clinical picture ranged from 60 to $120 \mathrm{mg}$ daily (average of $78.57 \mathrm{mg}$ daily).

Key words: cataract; Adrenal Cortex Hormones/therapeutic use; pemphigus; pemphigoid, bullous.
\end{abstract}

\footnotetext{
Recebido em 05.01.2003. / Received on January 05, 2004.

Aprovado pelo Conselho Consultivo e aceito para publicação em 07.08.2004. / Approved by the Consultive Council and accepted for publication on August 07, 2004.

* Trabalho realizado Universidade Federal de São Paulo - Escola Paulista de Medicina e noDepartamento de Dermatologia - Ambulatório de Dermatoses Bolhosas. / Work done at

"Universidade Federal de São Paulo - Escola Paulista de Medicina" and "Departamento de Dermatologia - Ambulatório de Dermatoses Bolhosas".

${ }^{t}$ Médica do curso de especialização em dermatologia (área eletiva) / M.D., Dermatology Specialization course (elective).

${ }^{2}$ Médica assistente e pós-graduanda (nível de doutorado); responsável pelo Ambulatório de Dermatoses Bolhosas / Assistant M.D. and Ph.D. candidate, head of the Bullous Dermatosis Outpatient Care Unit.

${ }^{3}$ Mestre em dermatologia e pós-graduanda (nível de doutorado). / Master's Degree and Ph.D. candidate

${ }^{4}$ Médica do curso de especialização em dermatologia (área eletiva). / M.D., Dermatology specialization course (elective)

${ }_{5}^{5}$ Professor adjunto / Adjunct professor.
} 


\section{INTRODUÇÃO}

Dermatoses bolhosas são doenças crônicas nas quais ocorre o aparecimento de bolhas em que se pode observar a participação de fenômeno auto-imune, mediante a imunoflorescência direta e indireta. Entre as mais freqüentes estão os pênfigos (vulgar e foliáceo) e o penfigóide bolhoso. A corticoterapia oral é utilizada como tratamento dessas doenças, muitas vezes em altas doses e por períodos prolongados.

Os efeitos colaterais dos corticosteróides são dose e tempo-dependentes. A toxicidade dos corticosteróides manifesta-se principalmente por meio de distúrbios hidroeletrolíticos, manifestações musculoesqueléticas, manifestações cutâneas, toxicidade gastrointestinal, complicações neurais, toxicidade endócrino-metabólicas, problemas oftálmicos e efeitos no sistema imunológico, com maior suscetibilidade a infecções.

No estudo de Lever \& White, ${ }^{1}$ os principais efeitos colaterais em 46 doentes com pênfigo foram: hiperglicemia em $45 \%$, alterações mentais em $35 \%$ e fratura de vértebra em $26 \%$.

Na publicação de Haim \& Shafir, ${ }^{2}$ a principal complicação em 35 doentes com pênfigo vulgar sob corticoterapia foi o desenvolvimento de características cushingóides em $48 \%$ deles.

Ryan $^{3}$ publicou avaliação de 70 doentes com pênfigo, sendo 44 com pênfigo vulgar, tratados com corticosteróides, e observou características cushingóides em $23 \%$, diabete em $23 \%$ e miopatia em $14 \%$.

Rosemberg e colaboradores ${ }^{4}$ publicaram a observação de 107 doentes com pênfigo, dos quais 57\% apresentaram características cushingóides, $44 \%$ infecção, $41 \%$ diabete e $29 \%$ osteoporose.

Cabrini e colaboradores ${ }^{5}$ observaram hiperglicemia em $44 \%$ de 16 doentes com pênfigo sob corticoterapia.

Lapidoth e colaboradores ${ }^{6}$ observaram em 15 pacientes com pênfigo tratados com corticosteróides: quatro casos de osteoporose, três de diabete, dois de hipertensão e um de catarata.

Mourellou e colaboradores ${ }^{7}$ publicaram a avaliação de 48 pacientes com pênfigo vulgar tratados com corticosteróides e observaram, em pacientes que receberam dose total de prednisona superior a cinco gramas, cinco casos de diabete, dois de broncopneumonia, dois de falência cardíaca congestiva, um de embolia pulmonar e um de psicose.

No Brasil, em trabalho de tese realizado por um dos autores, ${ }^{8}$ que avaliou 40 doentes com pênfigo vulgar submetidos a corticoterapia, foram observados como efeitos colaterais: características cushingóides $(47,5 \%)$, hipertensão arterial (32,5\%), diabete (20\%) e erupção acneiforme (10\%).

Outras complicações são referidas na literatura: necrose asséptica de cabeça de fêmur, ${ }^{9}$ exacerbação de balantidíase e estrongiloidíase, ${ }^{10,11}$ hemorragia e perfuração de porções inferiores do trato gastrointestinal ${ }^{12-15}$ e pneumonia. ${ }^{16}$

As duas principais complicações oftalmológicas da corticoterapia são a catarata subcapsular posterior e o glaucoma. ${ }^{17}$ Não foram encontrados na literatura trabalhos

\section{INTRODUCTION}

Bullous dermatoses are chronic diseases character ized by the appearance of chronic bullous dermatosis. By means of direct and indirect immunofluorescence, the par ticipation of an autoimmune phenomenon can be observed. Among the most frequent are pemphigus (vulgaris and foli aceous) and bullous pemphigoid. Oral corticotherapy is used as treatment of these diseases, often in very high doses and for prolonged periods of time.

The side effects of corticosteroids are dose-and timedependent. ${ }^{2}$ The toxicity of the corticosteroids is manifested mainly by hydroelectrolytic disturbances, musculoskeletal manifestations, cutaneous manifestations, gastrointestinal toxicity, neural complications, metabolic-endocrine toxicity, ophthalmic problems and effects on the immulogical system, with higher susceptibility to infections.

In a study by Lever and White, ${ }^{1}$ the main side effects in 46 patients with pemphigus were: hyperglycemia in $45 \%$, mental alterations in $35 \%$ and fractured vertebrae in $26 \%$. In a publication by Haim and Shafir, ${ }^{2}$ the main complication in 35 patients with pemphigus vulgaris was the development of cushingoid characteristics in $48 \%$ of them.

Ryan $^{3}$ published an assessment of 70 patients with pemphigus, 44 of who had pemphigus vulgaris. All patients were treated with corticosteroids. Cushingoid characteris tics were observed in $23 \%$ of them, diabetes in $23 \%$ and myopathy in $14 \%$.

Rosemberg and collaborators ${ }^{4}$ published an obser vation of 107 pemphigus patients, 57\% of whom showed cushingoid characteristics, $44 \%$ infection, $41 \%$ diabetes and $29 \%$ osteoporosis.

Cabrini and cols. ${ }^{5}$ observed hyperglycemia in $44 \%$ of 16 pemphigoid patients undergoing corticotherapy.

Lapidoth and cols. ${ }^{6}$ observed four cases of osteoporosis, three cases of diabetes, two of hypertension and one of cataract in 15 pemphigoid patients treated with corticosteroids.

Mourellou and cols. ${ }^{7}$ published an assessment of 48 patients with pemphigus vulgaris treated with corticos teroids. In patients who received a full dose of prednisone, i.e. above five grams, the authors observed five cases of diabetes, two of bronchopneumonia, two of congestive car diac failure, one of lung embolia and one case of psychosis.

In Brazil, a doctoral dissertation written by one of the authors ${ }^{8}$ evaluated 40 patients with pemphigus vulgaris submit ted to corticotherapy. The following side effects were observed: cushingoid characteristics (47.5\%), arterial hypertension (32.5\%), diabetes (20\%) and acneiform eruption (10\%).

Other complications referred to in the literature are: aseptic necrosis of femoral head, ${ }^{9}$ exacerbation of balan tidiasis and strongyloidiasis, ${ }^{10,11}$ hemorrhage and perfora tion of the lower parts of the gastrointestinal tract ${ }^{13-15}$ and pneumonia. ${ }^{16}$

The two main ophthalmologic complications in cor ticotherapy are posterior subcapsular cataract and glauco ma. ${ }^{17}$ There were no studies found in the literature assessing 
avaliando as complicações oculares da corticoterapia prolongada em pacientes com pênfigo e penfigóide.

\section{PACIENTES E MÉTODOS}

Trata-se de estudo retrospectivo, no qual foram incluídos 49 paciente portadores de pênfigo e penfigóide que estavam fazendo uso de corticóide oral e foram submetidos à avaliação oftalmológica. O diagnóstico da doença bolhosa foi confirmado por anatomopatológico.

Esses pacientes foram registrados no Ambulatório de Dermatoses Bolhosas do Departamento de Dermatologia da Universidade Federal de São Paulo/Escola Paulista de Medicina - Unifesp/EPM, no período de janeiro de 1987 a dezembro de 1997. Todos os pacientes que freqüentam esse ambulatório e fazem uso de corticóide oral são regularmente submetidos à avaliação oftalmológica na busca de complicações oculares decorrentes dtratamento. Essa avaliação é realizada no início do tratamento e, depois, regularmente a cada seis ou 12 meses, dependendo do caso.

Aavaliação oftalmológica no caso deste estudo constou de exame clínico, análise de acuidade visual e exame na lâmpada de fenda, com o objetivo de descobrir casos de catarata por corticoterapia. A catarata foi classificada de acordo com sua intensidade, variando de 1+ (grau leve) a 4+ (grau máximo).

Nos pacientes em que foi diagnosticada catarata por corticoterapia, essa ocorrência foi relacionada com as variáveis idade, sexo, grupo étnico, diagnóstico dermatológico, tempo de uso e corticosteróide utilizado.

\section{RESULTADOS}

1) Entre 49 pacientes, $14(28,57 \%)$ apresentaram catarata cortisônica (subcapsular posterior).

2) Características dos pacientes com catarata quanto ao sexo, idade, grupo étnico, diagnóstico, tipo e dose de corticosteróide usado (Quadro 1):

Dos 14 pacientes com catarata cortisônica, 11 são do sexo feminino e três do sexo masculino. A idade dos pacientes avaliados variou entre 33 e 77 anos de idade (média de 55 anos de idade).

Em relação ao grupo étnico, 12 pacientes eram caucasóides, e dois, negróides.

Quanto ao diagnóstico, nove dos pacientes estudados tiveram pênfigo vulgar, dois pênfigo foliáceo, dois penfigóide bolhoso, e um pênfigo herpetiforme.

O corticosteróide oral utilizado foi a prednisona, e a dose máxima necessária para controle do quadro clínico variou entre 60 e $120 \mathrm{mg} /$ dia (média de $78,57 \mathrm{mg} / \mathrm{dia}$ ).

3) Características da catarata quanto ao grau e o tempo de uso do corticosteróide até seu aparecimento (Quadro 2):

O tempo de uso de prednisona até o aparecimento da catarata variou de oito meses a nove anos e três meses (média de 45,71 meses). the ocular complications of prolonged corticotherapy in pemphigus and pemphigoid patients.

\section{PATIENTS AND METHODS}

The present survey is a retrospective study of 49 pem phigus and pemphigoid patients who used oral corticoids and were submitted to an ophthalmic evaluation. Diagnosis of the bullous disease was confirmed by anatomopathology.

The patients were registered at the Bullous Dermatosis Outpatient Care Unit of the Paulista Medical School, State University of Sao Paulo Dermatology Department (UNIFESP/EPM) from January 1987 to December 1997. All of the patients frequenting this outpa tient care unit and using oral corticosteroids are regular ly submitted to an ophthalmologic evaluation in a search for ocular complications resulting from the treatment. This evaluation is carried out at the beginning of treat ment, and then regularly every six to 12 months, depend ing on the case.

The ophthalmologic evaluation in this survey consisted of a clinical examination, analysis of visual acuity and slit-lamp examination, with the objective of discovering cases of cataract induced by corticotherapy. A cataract was classified according to its intensity, which varied from $1+($ slight $)$ to $4+$ (maximum degree $)$.

In the patients diagnosed with cataract induced by corticotherapy, its occurrence was related to variations in age, sex, ethnic group, dermatologic diagnosis, time of use and the corticosteroid used.

\section{RESULTS}

1) Among the 49 patients, 14 (28.57\%) presented with cortisone cataract (posterior subcapsular).

2) Characteristics of patients with cataract as to sex, age, ethnic group, diagnosis, type and dose of corticos teroid used (Chart 1):

Among the 14 patients with cortisone cataract, 11 were female and 3 male. The age of patients evaluated varied between 33 and 77 years (with an average of 55 years of age).

As for ethnic group, 12 patients were Caucasians, and two were Black.

As for the diagnosis, nine patients studied had pem phigus vulgaris, two foliaceous pemphigus, two bullous pemphigoid, and one pemphigus herpetiformis.

The oral corticosteroid used was prednisone. The maximum dosage necessary for control of the clinical con dition varied from 60 to $120 \mathrm{mg}$ daily (with an average of $78.57 \mathrm{mg}$ daily).

3) Characteristics of cataract regarding its degree and the time of corticosteroid use up to its first appearance (Chart 2):

The time of prednisone use up to the appearance of cataract varied from eight months to nine years and three months (average of 45.71 months).

The degree of cataract was incipient (2+), and (4+) 
Quadro 1: Distribuição dos pacientes quanto a sexo, idade (anos), grupo étnico, diagnóstico, tipo de corticosteróide utilizado e dose de controle / Chart 1: Patient distribution with respect to sex, age (years), ethnic group, diagnosis, type of corticosteroid used and control dose

\begin{tabular}{|c|c|c|c|c|c|c|}
\hline $\mathrm{N}^{\circ}$ & $\begin{array}{l}\text { Sexo } \\
\text { Sex }\end{array}$ & $\begin{array}{l}\text { Idade } \\
\text { Year }\end{array}$ & $\begin{array}{l}\text { Raça } \\
\text { Race }\end{array}$ & $\begin{array}{l}\text { Diagnóstico } \\
\text { Diagnosis }\end{array}$ & $\begin{array}{l}\text { Corticosteróide } \\
\text { Corticosteroid }\end{array}$ & $\begin{array}{l}\text { Dose }(\mathrm{mg} / \text { dia }) \\
\text { Dose }(\mathrm{mg} / \text { day })\end{array}$ \\
\hline 1 & $\mathrm{M}$ & 52 & C & $\begin{array}{l}\text { pênfigo vulgar } \\
\text { pemphigus vulgaris }\end{array}$ & $\begin{array}{l}\text { prednisona } \\
\text { prednisone }\end{array}$ & 120 \\
\hline 2 & $\mathrm{~F}$ & 50 & C & $\begin{array}{l}\text { pênfigo herpetiforme } \\
\text { pemphigus herpetiformis }\end{array}$ & $\begin{array}{l}\text { prednisona } \\
\text { prednisone }\end{array}$ & 120 \\
\hline 3 & $\mathrm{~F}$ & 52 & C & $\begin{array}{l}\text { pênfigo vulgar } \\
\text { pemphigus vulgaris }\end{array}$ & $\begin{array}{l}\text { prednisona } \\
\text { prednisone }\end{array}$ & 60 \\
\hline 4 & $\mathrm{~F}$ & 45 & C & $\begin{array}{l}\text { pênfigo vulgar } \\
\text { pemphigus vulgaris }\end{array}$ & $\begin{array}{l}\text { prednisona } \\
\text { prednisone }\end{array}$ & 100 \\
\hline 5 & $\mathrm{~F}$ & 73 & $\mathrm{C}$ & $\begin{array}{l}\text { penfigóide bolhoso } \\
\text { bullous pemphigoid }\end{array}$ & $\begin{array}{l}\text { prednisona } \\
\text { prednisone }\end{array}$ & 80 \\
\hline 6 & M & 48 & C & $\begin{array}{l}\text { pênfigo vulgar } \\
\text { pemphigus vulgaris }\end{array}$ & $\begin{array}{l}\text { prednisona } \\
\text { prednisone }\end{array}$ & 100 \\
\hline 7 & $\mathrm{~F}$ & 57 & $\begin{array}{l}\mathrm{N} \\
B\end{array}$ & $\begin{array}{l}\text { pênfigo vulgar } \\
\text { pemphigus vulgaris }\end{array}$ & $\begin{array}{l}\text { prednisona } \\
\text { prednisone }\end{array}$ & 80 \\
\hline 8 & $\mathrm{~F}$ & 77 & C & $\begin{array}{l}\text { pênfigo vulgar } \\
\text { pemphigus vulgaris }\end{array}$ & $\begin{array}{l}\text { prednisona } \\
\text { prednisone }\end{array}$ & 80 \\
\hline 9 & $\mathrm{~F}$ & 57 & $\mathrm{C}$ & $\begin{array}{l}\text { pênfigo vulgar } \\
\text { pemphigus vulgaris }\end{array}$ & $\begin{array}{l}\text { prednisona } \\
\text { prednisone }\end{array}$ & 80 \\
\hline 10 & $\mathrm{~F}$ & 33 & $\mathrm{C}$ & $\begin{array}{l}\text { pênfigo foliáceo } \\
\text { foliaceous pemphigus }\end{array}$ & $\begin{array}{l}\text { prednisona } \\
\text { prednisone }\end{array}$ & 60 \\
\hline 11 & $\mathrm{~F}$ & 67 & $\mathrm{C}$ & $\begin{array}{l}\text { pênfigo vulgar } \\
\text { pemphigus vulgaris }\end{array}$ & $\begin{array}{l}\text { prednisona } \\
\text { prednisone }\end{array}$ & 60 \\
\hline 12 & $\mathrm{~F}$ & 59 & $\mathrm{C}$ & $\begin{array}{l}\text { penfigóide bolhoso } \\
\text { bullous pemphigoid }\end{array}$ & $\begin{array}{l}\text { prednisona } \\
\text { prednisone }\end{array}$ & 60 \\
\hline 13 & $\mathrm{M}$ & 40 & $\mathrm{C}$ & $\begin{array}{l}\text { pênfigo vulgar } \\
\text { pemphigus vulgaris }\end{array}$ & $\begin{array}{l}\text { prednisona } \\
\text { prednisone }\end{array}$ & 40 \\
\hline 14 & $\mathrm{~F}$ & 60 & $\begin{array}{l}\mathrm{N} \\
B\end{array}$ & $\begin{array}{l}\text { pênfigo foliáceo } \\
\text { foliaceous pemphigus }\end{array}$ & $\begin{array}{l}\text { prednisona } \\
\text { prednisone }\end{array}$ & 60 \\
\hline
\end{tabular}

$\begin{array}{ll}\text { F: feminino / female } & \text { M: masculino / male } \\ \text { C: caucasóide / caucasian } & \mathrm{N} / \mathrm{B} \text { : negróide / black }\end{array}$

O grau de catarata foi de incipiente (2+) a (4+). Dez pacientes apresentaram catarata bilateral, e três, unilateral.

\section{DISCUSSÃO}

Os efeitos colaterais mais freqüentemente descritos pela corticoterapia oral são hipertensão, diabete (23 a 45\%), osteoporose, infecções (40\%), distúrbios hidroeletrolíticos e características cushingóides (23 a 57\%). ${ }^{12}$

A relação entre o uso crônico de corticoterapia oral e a formação de catarata subcapsular posterior foi originalmente at the most. Ten patients presented with bilateral cataract and three with unilateral.

\section{DISCUSSION}

The most frequent side effects induced by oral corti cotherapy to be described are hypertension, diabetes (23 to $45 \%)$, osteoporosis, infections (40\%), hydroelectrolytic dis turbances and cushingoid characteristics (23 to 57\%). ${ }^{12}$

The relation between the chronic use of oral corti cotherapy and the formation of posterior subcapsular 
Quadro 2: Característica da catarata quanto ao grau e ao tempo de uso do corticosteróide até seu desencadeamento / Chart 2: Characteristic of cataract regarding its degree and the time of corticosteroid use up to its first appearance

\begin{tabular}{|c|c|c|}
\hline $\mathrm{N}^{\mathrm{o}}$ & $\begin{array}{l}\text { Grau de catarata } \\
\text { Degree of cataract }\end{array}$ & $\begin{array}{l}\text { Tempo de uso de corticosteróide } \\
\text { Time of corticosteroid use }\end{array}$ \\
\hline 1 & $2+/ 4+$ bilateral $/ 2+/ 4+$ bilateral & 40 meses / months \\
\hline 2 & $2+/ 4+$ bilateral $/ 2+/ 4+$ bilateral & 53 meses / months \\
\hline 3 & $1+/ 4+$ bilateral $/ 1+/ 4+$ bilateral & 69 meses / months \\
\hline 4 & bilateral / bilateral & 39 meses / months \\
\hline \multirow[t]{2}{*}{5} & OD $1+/ 4+/ R E 1+/ 4+$ & \\
\hline & OE $2+/ 4+/ L E 2+/ 4+$ & 60 meses / months \\
\hline 6 & bilateral / bilateral & 8 meses / months \\
\hline 7 & $*$ & 12 meses / months \\
\hline 8 & avançada OE / advanced LE & 30 meses / months \\
\hline 9 & $\mathrm{OE} / L E$ & 42 meses / months \\
\hline 10 & $*$ & 46 meses / months \\
\hline 11 & $\mathrm{OE} / L E$ & 53 meses / months \\
\hline \multirow[t]{2}{*}{12} & OD $2+/ 4+/ R E 2+/ 4+$ & \\
\hline & OE $1+/ 4+/ L E 1+/ 4+$ & 28 meses / months \\
\hline 13 & $\begin{array}{l}\text { bilateral, mais acentuada no OD } \\
\text { bilateral, more accentuated in } R E\end{array}$ & 111 meses / months \\
\hline \multirow[t]{2}{*}{14} & OD $1+/ 4+/ R E 1+/ 4+$ & \\
\hline & OE $2+/ 4+/ L E 2+/ 4+$ & 48 meses / months \\
\hline
\end{tabular}

OD: olho direito / right eye

OE: olho esquerdo / left eye

*o laudo do oftalmologista foi catarata cortisônica, sem melhor caracterização clínica

*the ophthalmologist's report was cortisone cataract, without better clinical characterization

proposta por Black e colaboradores em $1960 .{ }^{18}$ Nesse estudo foi de especial interesse o fato de que a catarata subcapsular posterior não foi observada nos pacientes tratados por menos de um ano ou naqueles tratados por período inferior a quatro anos com doses baixas. Portanto, a dose e a duração do tratamento foram considerados diretamente proporcionais ao desenvolvimento da catarata. Os tipos cortisônico e senil diferenciam-se por ser o primeiro subcapsular posterior e o último nuclear.

A diminuição da visão é rara nos pacientes com catarata por corticoterapia, e o grau de prejuízo visual varia com a extensão da opacificação. Na maioria dos casos as alterações visuais são ausentes ${ }^{19,20}$ ou mínimas. ${ }^{21}$ Fotofobia insignificante ou distúrbio visual na luz (claridade) podem ocorrer. Uma vez a visão afetada pela catarata subcapsular posterior, não se pode esperar a completa resolução da opacificação lenticular, mesmo com redução da dose ou até mesmo com a interrupção da corticoterapia. Em um pequeno número de pacientes, foi observada diminuição da área de opacidade após redução ou interrupção da corticoterapia. ${ }^{18,23}$ cataract was originally put forward by Black and collabora tors in 1960. ${ }^{18}$ That study proved to be of special interest in that posterior subcapsular cataract had not been observed in patients in treatment for less than a year, or in those treated for less than four years at low doses. Nonetheless, the dose and duration of treatment were considered directly propor tional to the development of the cataract. Cortisone-type and senile cataracts differ insofar as the former is posterior subcapsular and the latter is nuclear.

Reduced vision is rare in patients with cataract induced by corticotherapy. The degree of sight impairment varies with the extension of the opacification. In most cases, visual alterations are absent, ${ }^{19,20}$ or minimal. ${ }^{21}$ Insignificant photophobia or visual disturbance in (bright) light might occur. So long as vision is affected by the posterior subcapsu lar cataract, one cannot expect complete resolution of the lenticular opacification, even by tapering the dose of corti cotherapy, or interrupting it. In very few patients, a reduction of the opacification area was observed after tapering or inter - 
Em alguns casos, portanto, mesmo com a interrupção do tratamento, ocorre progressão da catarata. ${ }^{24,25}$

Muitos estudos mostram que o efeito do corticosteróide na indução da catarata varia conforme a susceptibilidade do paciente ${ }^{23,27}$ A dose total de corticosteróide utilizado, bem como o tempo de uso, é significantemente importante, mas deve-se lembrar da influência da resposta individual do paciente ao corticosteróide.

Vários fatores parecem influenciar a indução da catarata pelo corticosteróide, entre eles:

- inibição da bomba Na K ATPase: os corticosteróides têm mostrado afetar o transporte de água e aumentar a permeabilidade das lentes oculares aos cátions. Clinicamente, a hidratação das lentes é manifestada ou pela intumescência generalizada, ou pelo acúmulo generalizado de fluído de índice de refração diferente da média circunvizinha, que é responsável, em parte, pela dispersão da luz e conseqüente diminuição de sua transmissão pelas lentes; ${ }^{28}$

- ligação dos corticosteróides às proteínas das lentes e conseqüente formação de pontes lisina-cetosteróides: a indução da opacificação do cristalino pelos corticosteróides seria então associada à formação de uma ligação covalente glucocorticosteróides-proteínas do cristalino; ${ }^{29,30}$

- oxidação secundária do grupo de proteínas-SH da ponte lisina-cetosteróides levando à agregação do cristalino: ${ }^{34}$ os glucocorticosteróides causariam catarata por penetrar as células da lente e reagir com aminogrupos específicos do cristalino, induzindo a uma alteração na conformação e expondo os grupos protéicos dissulfídicos. Esses grupos são então liberados de sua forma de ligação dissulfídica, o que leva subseqüentemente a uma agregação protéica e finalmente a complexos que refratam a luz.

A catarata cortisônica é raramente citada como efeito colateral no tratamento de pacientes com pênfigo e penfigóide. No Ambulatório de Dermatoses Bolhosas da Unifesp/EPM os autores observaram que $14(28,57 \%)$ dos 49 pacientes sob corticoterapia apresentaram catarata subscapsular posterior como efeito colateral do tratamento, após período médio de uso de 45,71 meses.

Ressaltam, nesse sentido, a necessidade da realização periódica de exame oftalmológico em pacientes com dermatoses bolhosas sob corticoterapia. A prevalência por eles observada no presente estudo foi próxima de $30 \%$; foram encontrados pacientes relativamente jovens ( 33 anos) e em uso de corticoterapia não muito prolongada (oito meses). $\mathrm{O}$ fato de os pacientes apresentarem, em geral, alterações mínimas de acuidade visual reforça a necessidade da busca ativa da catarata cortisônica por meio do exame oftalmológico regular.

\section{CONCLUSÕES}

Em portadores de pênfigo e penfigóide submetidos à corticoterapia oral observou-se que:

1) a catarata foi um dos importantes efeitos colaterais manifestados;

2) a prevalência de catarata foi de $28,57 \%$; rupting the corticotherapy. ${ }^{18,23}$ In some cases, however, even after interrupting treatment, the cataract tends to progress. ${ }^{24,25}$

Several studies show that the effect of a corticos teroid on inducing cataract varies according to the patient's susceptibility. ${ }^{23,27}$ The total dosage of corticosteroid utilized, as well as the time of its use, is significantly important, but the influence of the patient's individual response to corti costeroid must be recalled:

Various factors seem to influence the induction of cataract by corticosteroid, among which are:

- inhibition of the Na-K ATPase pump: corticos teroids have been known to affect water transportation and increase the permeability of ocular lenses to cations. Clinically, hydration of the lenses is manifested either by gen eralized intumescence, or by generalized accumulation of fluid whose refraction index is different from the surrounding average, and is responsible in part for the dispersion of light and consequent reduction of its transmission by the lenses, ${ }^{28}$

- link of corticosteroids to lens proteins and conse quent formation of lysine-ketosteroid adducts: induction of crystalline opacification by corticosteroids would occur in association with the formation of the crystalline's glucocor ticosteroid protein covalent bond; ${ }^{29,30}$

- secondary oxidation of the SH-protein group of the lysine-ketosteroid adduct leading to crystalline aggregate formation: ${ }^{34}$ the glucocorticosteroids seem to cause cataract by penetrating the lens cells and reacting with spe cific crystalline amino groups, thereby inducing an alter ation in the confirmation and exposure of protein disulfide groups. These groups are then released from their disulfide bond form, which subsequently leads to a protein aggregate formation and finally to the light-refracting complexes.

Cortisone cataract is rarely cited as a side effect from treating pemphigus and pemphigoid patients. At the UNIFE SP/EPM Bullous Dermatosis Outpatient Care Unit, the authors observed that 14 (28.57\%) of the 49 patients under corticother apy showed posterior subcapsular cataract as a side effect of treatment, after an average period of 45.71 months.

As such, they emphasized the need to periodically carry out an ophthalmologic examination of patients with bullous dermatoses who are undergoing corticotherapy. The prevalence observed in the present survey was roughly $30 \%$. Relatively young patients (33 years) and those who had not been under prolonged corticotherapy use (eight months) were found to be affected. The fact that patients usually showed slight alterations of visual acuity reinforces the need for an active search of cortisone cataract by means of regular ophthalmologic examinations.

\section{CONCLUSIONS}

In pemphigus and pemphigoid patients submitted to oral corticotherapy, the following could be observed:

1) the cataract was one among the important side effects manifested;

2) prevalence of the cataract was $28.57 \%$; 
3) a catarata cortisônica pode ser unilateral ou bilateral;

4) o tempo médio de tratamento até o surgimento de catarata foi de 45,71 meses;

5) a média da dose máxima de corticosteróide utilizada pelos pacientes foi de 78,57mg/dia.

\section{AGRADECIMENTOS}

Setor de Catarata do Departamento de Oftalmologia da Escola Paulista de Medicina/Unifesp.

\section{REFERÊNCIAS / REFERENCES}

1. Lever WF, White H. Treatmente of pemphigus with corticosteroids: results obteined in 46 patients over a period of 11 years. Arch Dermatol. 1963; 87:52-66.

2. Haim S, Shafrir A. Remarks on the treatment of pemphigus vulgaris. Dermatologica. 1970;141:270-6.

3.Ryan JG. Pemphigus: a 20-year survey of experience with 70 cases. Arch Dermatol. 1971;104:14-20.

4. Rosenberg FR, Sanders S, Nelson CT. Pemphigus: a 20-year review of 107 patients treated with corticosteroids. Arch Dermatol. 1976; 112:962-70.

5. Cabrini JM, Margasin S, Mercau A, Recarte M, Vacirca E. Comentarios sobre un grupo de pacientes de penfigo atendidos en el policlinico I. Carrasco en los ultimos 10 años. Rev Arg Derm. 1984; 65:289-92.

6. Lapidoth $\mathrm{M}$ e cols. The efficacy of combined treatment with prednisone and cyclosporine in patients with pemphigus: preliminary study. J Am Acad Dermatol. 1994; 30(5 Pt1): 752-7.

7. Mourellou $\mathrm{O}$ e cols. The treatment of pemphigus vulgaris. Experience with 48 patients seen over an 11-year period. Br J Dermatol. 1995; 133:83-7.

8. Porro AM, Castro RM. Avaliação da resposta terapêutica e evolução em 40 doentes com pênfigo vulgar. Thesis paper. 1992; 140 p.

9. Cardama JE, Charosky CB, Jaled MM, Selva JS, Bassino BM, Baldanza R. Necrosis asética de cabeza de femur por corticoterapia prolongada en pacientes portadores de penfigo. Rev Arg Derm. 1981; 62:155-9.

10. D'Andreatta I. Exacerbação de balantidíase e estrongiloidíase em paciente com pênfigo foliáceo sul americano na vigência de corticoterapia. Ver Hosp Clin Fac Med S Paulo. 1980; 35:88-90. 11. Sarubbi F A. Hyperinfection with Strongyloides during treatment of pemphigus vulgaris. Arch Dermatol. 1987; 123:864-5 (Letter). 12. Ashworth J, Cox NH, Pickard WR, Mackay C, Roberts DT. Death in pemphigus vulgaris caused by lower gastrotrointestinal hemorrhage. J Am Acad Dermatol. 1987; 16: 394-5 (Letter).

13. Lauber JS, Abrams, HL, Ray MC. Silent bowel perforation occurring during corticosteroid treatment for pemphigus vulgaris. Cutis. 1989; 43: 27-8.

14. Epstein A, Trattner A, David M, Sandbank M. Perforation of colon diverticula during corticosteroid therapy for pembphigus vulvaris. Ann Pharmacother. 1993; 27: 979-80 (Letter).

15. Sharma R, Gupta KL, Ammon RH, Gambert SR. Departament of Medicine, New York Medical College, Valhalla, USA. Atypical presentation of colon perforation related to corticosteroid use. Geriatrics. 1997; 52: 88-90.

16. Murdock DK, Lookingbill DP. Immunosuppressive therapy of pemphigus vulgaris complicated by Nocardia pneumonia. Arch
3) the cortisone cataract might be unilateral or bilateral;

4) average time of treatment up to the appearance of the cataract was 45.71 months;

5) average maximal dose of corticosteroid utilized by patients was $78.57 \mathrm{mg}$ daily.

\section{ACKNOWLEDGEMENTS}

The authors kindly thank the Cataract Section of the Paulista Medical School/UNIFESP Ophthalmology Department.

Dermatol. 1990; 126:27-8.

17. Jack J Kanske. Chapter 8. In: Clinical Ophtalmologyc. Butterworth. Heinemann International Edition 1989; 234-59.

18. Black RL, Oglesby RB, von Sallmann L et al. Posterior subcapsular cataracts induced by corticosteroids in patients with rheumatoid arthritis. JAMA. 1960; 174:166-71.

19. Bihari M, Grossman BJ. Posterior subcapsular cataracts. Related to long-term corticosteroid treatment in children. Am J Dis Child. 1968; 116:604-8.

20. Havre DC. Cataracts in children on long-term corticosteroid therapy. Arch Ophthalmol. 1965; 3:818-21. 25.

21. Mino M, Ueda Y, Hayashi M et al. Posterior subcapsular cataract in children on longterm corticoid therapy. Acta Paediatr Jpn. 1969; 11:1-5.26.

22. Forman AR, Loreto JA, Tina LU. Reversibility of corticosteroid - associated cataracts in children with the nephrotic syndrome. Am J Ophtalmol. 1977; 84:75-8.

23. Dikshit SK, Avasthi PN. Posterior lenticular opacities in children on corticosteroid therapy. Indian J Pediatr. 1965; 32:93-6.

24. Loredo A, Rodriguez RS, Murillo L. Cataracts after short-term corticosteroid treatment. N Engl J Med. 1972; 286:160.

25. Rooklin AR, Lampert SI, Jaeger EA et al. Posterior subcapsular cataracts in steroid-requiring asthmatic children. J Allergy Clin Immunol. 1979; 63:383-6.

26. Skalka HW, Prchal JT. Effect of corticosteroids on cataract formation. Arch Ophthalmol. 1980; 98:1773-7.

27. Harris JE, Gruber L. The electrolyte and water balance of the lens. Exp Eye Res. 1962; 1:372-84.

28. Bucala R, Fishman J, Cerami A. Formation of covalent adducts bethewen cortisol and 16 alpha-hydroxyestrone and protein: possible hole in the pathogenesis of cortisol toxicity and systemic lupus erythematosus. Proc Natl Acad Sci USA. 1982; 79:3320-4.

29. Manabe S, Bucala R, Cerami A. Nonenzymatic addition of glucocorticoids to lens proteins in steroid-induced cataracts. J Clin Invest. 1984; 74:1803-10.

30. Bucala R, Manabe S, Urban RC Jr et al. Nonenzymatic modification of lens crystallins by predinisolone induces sulfhydryl oxidation and aggregate formation: In vitro and in vivo studies. Exp Eye Res. 1985; 41:353-63.

\section{ENDEREÇO PARA CORRESPONDÊNCIA: / M AILING AdDRESS: \\ Viviane Reggiani \\ Rua Pedro de Toledo, 130 conjunto 55 - V. Mariana 04031-000 São Paulo SP}

Tel.: (11) 5084-3097 